\title{
PERANCANGAN APLIKASI PENGADAAN BARANG PADA PT PUPUK SRIWIDJAJA (Persero) KANTOR PEMASARAN PUSRI DAERAH LAMPUNG
}

\author{
RIFKI PUSPA WARDANI*1 \\ Jl. Zainal Abidin Pagar Alam No. 26 \\ Labuhan Ratu Bandar Lampung 35142
}

\begin{abstract}
PT pupuk Sriwidjaja merupakan perusahaan yang bergerak di bidang penjualan pupuk, baik dengan cara tunai ataupun dengan cara kredit. Dalam proses penjualan secara kredit, sampai saat ini perusahaan tersebut masih menggunakan cara manual sehingga dalam proses pengolahan datanya masih sering terjadi kesalahan dan kurang cepat. Oleh karena itu penulis membuat suatu sistem yang dapat digunakan pada perusahaan tersebut. Sistem yang penulis buat menggunakan bahasa pemrograman Visual Basic dan menggunakan database Microsoft Access. Tujuan dari dibuatnya sistem ini yaitudapat mempermudah proses pengolahan data penjualan kredit, lalu dapat mempercepat proses pencarian data dan dalam pembuatan laporan.

Pembuatan laporan praktek kerja lapangan ini, penulis menggunakan beberapa metode pengumpulan data yaitu dengan cara wawancara atau tanya jawab secara langsung dengan pihak yang mengetahui mekanisme yang berhubungan dengan masalah yang penulis bahas, kemudian dengan cara pengamatan langsung pada perusahaan dan yang terakhir dengan cara tinjauan pustaka dari buku-buku penunjang.
\end{abstract}

Keywords:Penjualan,Kredit,Database

\section{PENDAHULUAN}

\subsection{Latar Belakang}

Setiap perusahaan menginginkan kegiatannya berjalan dengan baik. Untuk itu dalam menjalankan kegiatannya, perusahaan membutuhkan alat-alat pendukung untuk menjalankan kegiatan tersebut. Baik itu mesin atau Sumber Daya Manusia (SDM) itu sendiri, sesuai dengan perkembangan teknologi. Sehingga diharapkan dapat menghasilkan informasi yang berguna, yang dibutuhkan oleh semua pihak terutama untuk bagian pengadaan. Dengan begitu pengelolahan pengadaan barang pada perusahaan tersebut dapat ditangani dengan baik.

\section{Rumusan Masalah}

Melihat dan memperhatikan latar belakang yang dikemukakan di atas, maka dapat dirumuskan suatu permasalahan yang terjadi yaitu bagaimana system pengadaan barang pada PT Pupuk Sriwidjaja dengan menggunakan aplikasi yang lebih baik dari sebelumnya sehingga hasil yang didapatkan akan semakin lebih baik.

\subsection{Batasan Masalah}

Berdasarkan latar belakang yang diuraikan di atas, maka penulis tidak meungkin mampu membahas semua permasalahan yang ada disebabkan keterbatasan waktu dan tenaga maka penulis hanya membatasi permasalahan mengenai pengadaan barang pada PT Pupuk Sriwidjaja tersebut.

\subsection{Tujuan Penelitian}

Adapun tujuan yang ingin dicapai dari penelitian di PT Pupuk Sriwijaja (Persero) pada Kantor Pemasaran Pusri Daerah Lampung adalah:

1. Merancang suatu sistem pengadaan dengan menggunakan bahasa pemrograman Visual Basic versi 6.0 dan dengan menggunakan databaseMicrosoft Access 2000

2. Mengaplikasikan sistem pengadaan barang yang telah penulis rancang, sehingga diharapkan dapat meningkatkan efektifitas dan dapat mempermudah dalam pembuatan laporan pada bagian pengadaan barang.

\section{Metodologi Penelitian}

Keterangan yang diperoleh dalam pengumpulan data dan informasi yang aktual dalam rangka menyusun skripsi ini penulis menggunakan beberapa metode-metode sebagai berikut:

\section{Wawancara (Interview)}

Pengumpulan data dengan metode interview yaitu metode pengumpulan data yang dilakukan dengan cara tanya jawab secara langsung dengan pihak yang mengetahui mekanismenya dan hal yang berhubungan dengan masalah yang penulis bahas sehingga dapat memberikan informasi yang jelas dan benar. 


\section{Pengamatan (Observation)}

Pengumpulan data dengan metode observation yaitu pengumpulan data yang dilakukan melalui pengamatan dan pencatatan secara langsung, mempelajari segala sesuatu yang berhubungan dengan sistem yang sedang berjalan di perusahaan tersebut sehingga penulis dapat mengambil kesimpulan dari penelitian tersebut.

\section{Tinjauan Pustaka (Library Research)}

Metode tinjauan pustaka yaitu dilakukan dengan cara membaca, mencatat, mengutip dan mengumpulkan data-data secara teoritis dari bukubuku yang berhubungan dengan penulisan skripsi.

\section{LANDASAN TEORI \\ 4.1 Konsep Dasar Sistem \\ 4.1.2 Pengertian Sistem}

Terdapat dua kelompok pendekatan di dalam mendefinisikan sistem, yaitu yang menekankan pada prosedurnya dan yang menekankan pada komponen atau elemennya.

Pendekatan sistem yang lebih menekankan pada prosedur mendefinisikan sistem sebagai berikut :

Menurut Jogiyanto (1999:56) "Sistem adalah suatu jaringan kerja dari prosedur-prosedur yang saling berhubungan, berkumpul bersama-sama untuk melakukan suatu kegiatan atau untuk menyelesaikan suatu sasaran yang tertentu".

\subsubsection{Pengertian Informasi}

Pengertian informasi menurut Jogiyanto (1999:8) adalah "Data yang telah diolah sehingga menjadi bentuk yang dapat bermanfaat atau berguna bagi penerimanya.

\subsubsection{Pengertian Sistem Informasi}

Pengertian sistem informasi menurut Jogiyanto (1999:11) adalah "Suatu organisasi yang mempertemukan kebutuhan pengolahan transaksi harian, mendukung operasi, bersifat manajerial, dan kegiatan strategi dari suatu organisasi dan menyediakan pihak luar tertentu dengan laporanlaporan yang diperlukan".

\subsubsection{Karakteristik Sistem}

Sistem mempunyai karakteristik atau sifat-sifat tertentu yaitu:

1. Komponen Sistem (Component System)

Sistem mempunyai kumpulan komponenkomponen yang saling berinteraksi membentuk satu kesatuan.

2. Batasan Sistem (Boundary System)
Batasan sistem merupakan daerah yang membatasi antara suatu sistem dengan sistem yang lainnya atau lingkungan luarnya.

3. Lingkungan luar Sistem (Environment System) Lingkungan luar sistem yaitu apapun diluar batas dan sistem yang mempengaruhi operasi sistem itu sendiri.

4. Penghubung Sistem (Interface System)

Penghubung sistem merupakan media penghubung antara sub sistem satu dengan sub sistem yang lainnya.

5. Masukan Sistem (Input System)

Masukansistem yaitu energi yang dimasukkan ke dalam sistem yang dapat berupa perawatan (maintenance input) serta masukan signal (signal input).

6. Keluaran Sistem (Output System)

Keluaran sistem merupakan hasil dari energi yang diolah dan diklasifikasikan menjadi keluaran yang berguna dari sisa pembuangan.

7. Pengolahan Sistem (Process System)

Suatu sistem dapat mempunyai suatu bagian pengolah yang akan berubah masukan menjadi keluaran.

8. Sasaran Sistem (Goal sistem)

Suatu sistem pasti mempunyai tujuan (goal) atau sasaran (objective). Bila suatu sistem tidak mempunyai sasaran, maka operasi sistem tidak ada gunanya. Sasaran dari sistem sangat menentukan sekali masukan yang dibutuhkan sistem dan keluaran yang akan dihasilkan sistem.

\subsubsection{Pengertian Data}

Data adalah hal, peristiwa/kenyataan lainnya apapun yang mendukung suatu pengolahan untuk dijadikan dasar guna menyusun keterangan, perbuatan, kesimpulan/penetapan keputusan. Data ibarat bahan mentah yang melalui pengolahan tertentu menjadi keterangan atau informasi (Moekijat: 1989:7)

\subsubsection{Pengolahan Data}

Pengolahan data adalah sebagai sebuah mekanisme untuk menerima data, mengkomunikasikan ke berbagai pihak yang berkepentingan menyimpan, memproses dan menyajikannya dalam berbagai bentuk laporan, untuk mendukung segenap fungsi dalam sebuah perusahaan (Edi Purwono: 2002:23)

\subsubsection{Pengertian Perancangan}

Menurut Edi Purwono (2002:33) perancangan sistem merupakan kegiatan untuk pengembangan sistem dan prosedur baru dalam kaitannya dengan sasaran-sasaran (baru) yang dikehendaki oleh pihak manajemen, untuk memperoleh suatu sistem yang mampu dipakai 
untuk memanajemeni perusahaan secara lebih efektif dan efisien.

\section{Pengertian Aplikasi}

Menurut Tim Penyusun Kamus Pusat Pembinaan dan Pengembangan Bahasa (1997) "aplikasi adalah suatu program yang sudah jadi dan sudah dapat digunakan atau diterapkan oleh pengguna/user".

\section{Pengadaan}

Secara umum istilah pengadaan adalah proses mengadakan barang untuk memenuhi persediaan sesuai dengan kebutuhan untuk digunakan sendiri atau untuk dijual kembali.

\section{MicrosoftVisual Basic 6.0}

Visual Basic adalah sebuah bahasa pemograman yang digunakan untuk membuat program aplikasi berbasis orientasi objek atau Object Oriented Program (OPP) (Agung Novian: 2004:5).

2.9.1 Lingkungan Visual Basic 6.0

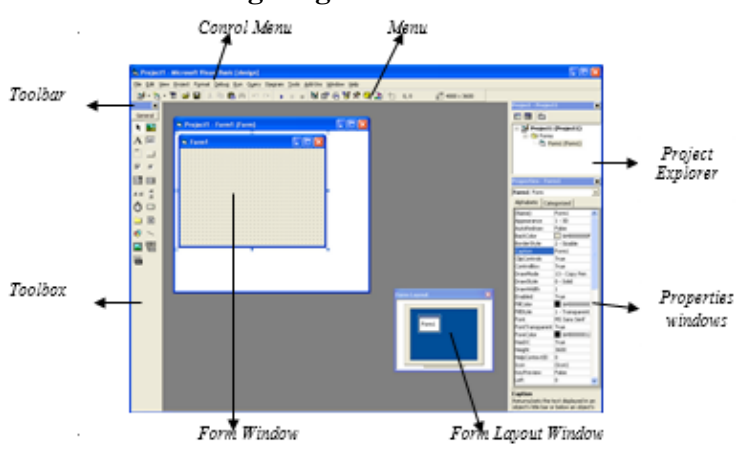

Pemrograman Microsoft Access 2000

Microsoft Access 2000 merupakan salah satu program pengolah database yang canggih, yang digunakan untuk mengolah berbagai jenis data dengan pengoperasian yang mudah. Banyak kemudahan yang ditawarkan Microsoft Access misalnya penyortiran, pengaturan data, pembuatan label data serta pembuatan laporan kegiatan seharihari.

Bagan Alir Dokumen (Document Flowchart)

Bagan alir dokumen (Document Flowchart) merupakan bagian yang menunjukkan alir (flow) di dalam program atau prosedur sistem secara logika. Bagan alir sistem merupakan bagan yang menunjukkan arus pekerjaan secara keseluruhan dari sistem. Bagan ini menjelaskan urutan-urutan dari prosedur-prosedur yang ada di dalam sistem. Bagan alir sistem menunjukkan apa yang dikerjakan sistem.

\section{Bagan Alir Program (Flowchart Program)}

"Bagan Alir program (flowchart program) merupakan bagan yang menjelaskan secara rinci langkah-langkah dari proses program, dibuat dari verifikasi bagan alir dokumen." (Jogiyanto: 1999: 802)

\section{Data Flow Diagram (Diagram Arus Data)}

Data flow diagram (DFD) adalah peralatan yang digunakan pada metodologi pengembangan sistem yang berfungsi menggambarkan secara rinci mengenai sistem jaringan kerja antar fungsi yang berhubungan satu dengan yang lainnya yang menunjukkan dan kemana data alir mengalir serta penyimpanannya (Leman: 2001: 122).

\section{Entity Relation Diagram (E-R Diagram)}

Entity Relation Diagram adalah "Berisi komponen-komponen himpunan entitas dan himpunan relasi yang masing-masing dilengkapi dengan atribut-atribut yang mempresentasikan seluruh fakta dari dunia nyata yang kita tinjau". (Fathansyah, 1999:70)

\section{ANALISA MASALAH DAN PERANCANGAN SISTEM \\ Objek yang diteliti}

Penelitian ini, penulis lakukan pada perusahaan yang bergerak di bidang jasa penjualan pupuk yang bernama PT Pupuk Sriwidjaja (PUSRI). PT Pupuk Sriwidjaja (PUSRI) adalah salah satu perusahaan jasa yang ada di Bandar Lampung. Dalam melakukan atau melaksanakan pengadaan barang, sampai saat ini PT Pupuk Sriwidjaja (PUSRI) belum menerapkan sistem komputerisasi.

\section{Analisa Sistem Berjalan}

Alur proses pengadaan barang pada PT Pupuk Sriwidjaja (PUSRI) yaitu dimulai dari distributor datang ke kantor Pusri PPD Lampung, kemudian distributor tersebut membuat surat permohonan pembelian pupuk ke PPD di bagian penjualan.

\section{Uraian Masalah}

Setelah melakukan analisis terhadap sistem yang sedang berjalan, penulis mengusulkan rancangan sistem pengadaan barang pada PT Pupuk Sriwidjaja (PUSRI) berbasis komputer dengan menggunakan bahasa Pemograman Visual Basic 6.0, untuk membantumenyelesaikan permasalahan yang ada, sehingga dalam melakukan pembuatan laporan pengadaaan barang PT Pupuk Sriwidjaja (PUSRI) akan lebih mudah.

\section{Tujuan Analisis Sistem}

Analisis sistem ini dilakukan dengan tujuan untuk dapat mengetahui kelemahan sistem yang sudah ada sehingga dapat dicarikan solusi yaitu dengan membuat sistem pengadaan barang, menggunakan bahasa pemograman Visual Basic 6.0. 


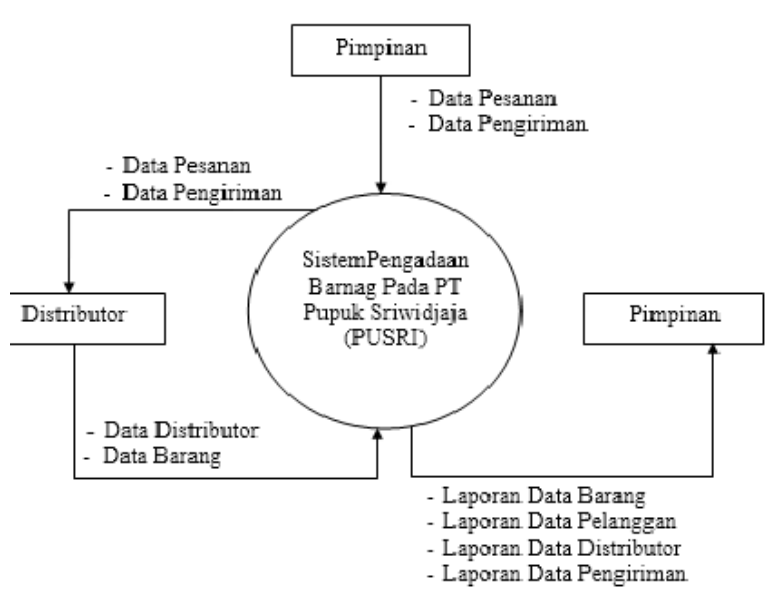

\section{Rancangan Diagram Level 0 Sistem Baru}

Data flow diagram merupakan representasi dari kebutuhan sistem yang di buat atau digunakan. DFD ini mendokumentasikan proses alir dari sistem berdasarkan diagram konteks di atas. Penjelasan dari sistem pengadaan barang pada PT Pupuk Sriwidjaja (PUSRI) dapat dilihat lebih jelasnya pada Gambar 3.4 di bawah ini:

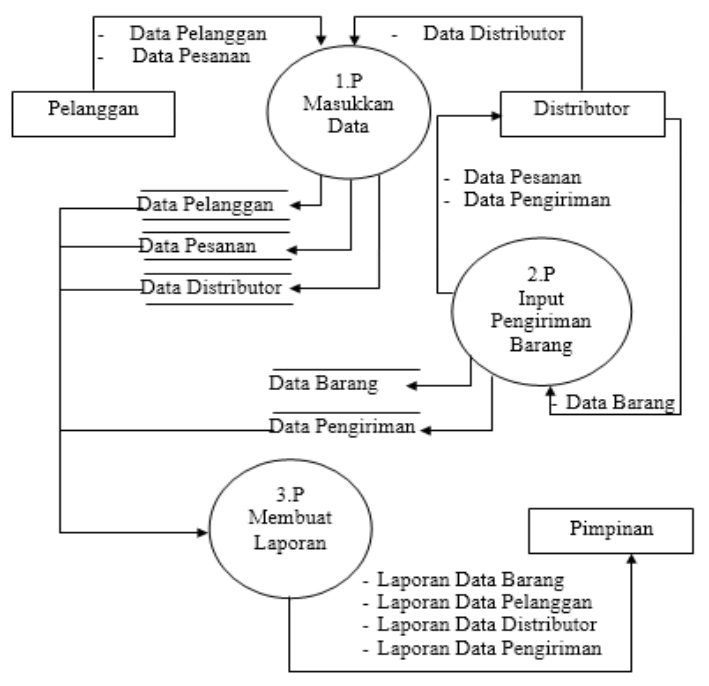

Gambar 3.3 Diagram Level 0 Rancangan

\section{Desain Database}

Desain database merupakan desain dari fieldfield pada file yang mendukung database dari rancangan sistem. Database sistem .pengadaan barang ini terdiri dari lima buah tabel, yang memiliki tipe data yang berbeda-beda sesuai dengan kebutuhan pengolahan datanya.

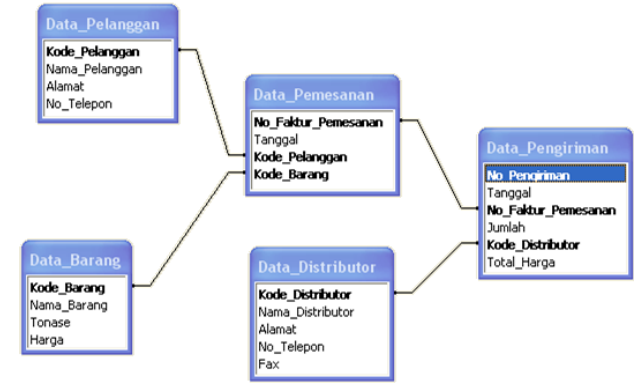

\section{Relasi Antar Tabel}

Relasi Antar Tabel merupakan model basis data yang mudah untuk diterapkan karena model basis data ini menunjukkan suatu cara atau mekanisme yang digunakan untuk mengelola data secara fisik dalam memori sekunder yang akan berdampak pula pada bagaimana kita mengelompokkan dan membentuk keseluruhan data yang terkait dalam sistem yang kita rancang.

\section{Rancangan Program}

\section{Rancangan Password}

Rancangan password yang akan dibuat, dapat dilihat dari gambar 3.7 di bawah ini:

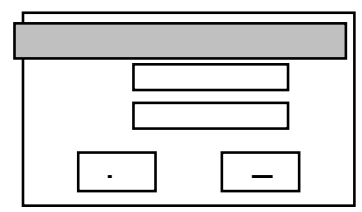

Gambar 3.7 Rancangan Password

\section{ANALISA MASALAH DAN PERANCANGAN SISTEM Objek yang diteliti \\ Penelitian ini, penulis lakukan pada} perusahaan yang bergerak di bidang jasa penjualan pupuk yang bernama PT Pupuk Sriwidjaja (PUSRI). PT Pupuk Sriwidjaja (PUSRI) adalah salah satu perusahaan jasa yang ada di Bandar Lampung.

\section{Analisa Sistem Berjalan}

Alur proses pengadaan barang pada PT Pupuk Sriwidjaja (PUSRI) yaitu dimulai dari distributor datang ke kantor Pusri PPD Lampung, kemudian distributor tersebut membuat surat permohonan pembelian pupuk ke PPD di bagian penjualan. 


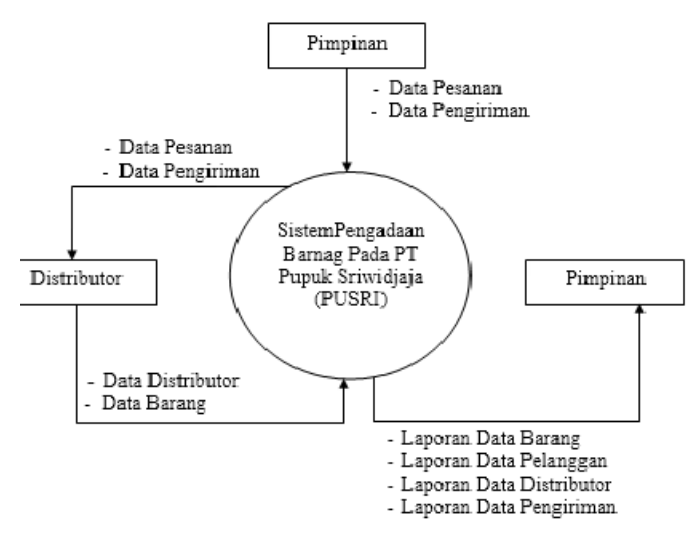

\section{Relasi Antar Tabel}

Relasi Antar Tabel merupakan model basis data yang mudah untuk diterapkan karena model basis data ini menunjukkan suatu cara atau mekanisme yang digunakan untuk mengelola data secara fisik dalam memori sekunder yang akan berdampak pula pada bagaimana kita mengelompokkan dan membentuk keseluruhan data yang terkait dalam sistem yang kita rancang.

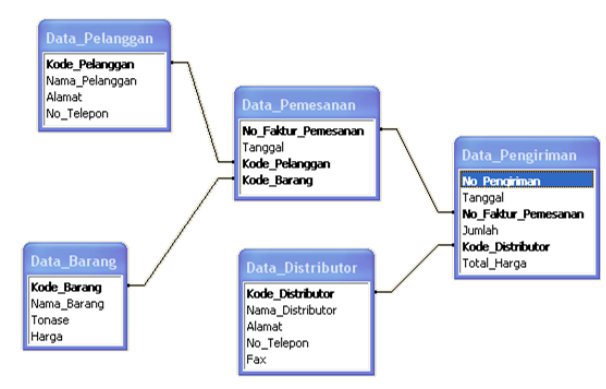

\section{PEMBAHASAN}

\section{Implementasi Sistem Baru}

Program yang telah dibuat digunakan oleh bagian penjualan sesuai dengan fungsinya. Bagian penjualan menginput data pengandaan barang kedalam sistem baru, sehingga dalam pencarian data dan pembuatan laporan akan lebih mudah dan tepat waktu.

\section{Perangkat Pendukung Implementasi Sistem Komputerisasi \\ Perangkat Keras Komputer (Hardware)}

Untuk pembuatan program peminjaman, menggunakan perangkat keras yang mendukung program agar dapat berjalan dengan baik. Perangkat keras yang digunakan oleh PT Pupuk Sriwidjaja (PUSRI) PPD Lampung untuk sistem pengadaan barang ini terdiri dari:

1. Komputer Pentium IV

2. $\operatorname{Ram} 256 \mathrm{Mb}$
3. Harddisk $80 \mathrm{~GB}$
4. Disk Drive $3^{1 / 2}$ Floppy
5. CD ROM $52 \mathrm{x}$
6. Monitor 17" Flat
7. Keyboard
8. Mouse

\section{Perangkat Lunak (Software)}

Agar program dapat dijalankan, komputer harus dilengkapi dengan perangkat lunak yang mendukung sistem tersebut. Perangkat lunak yang digunakan terdiri sistem operasi WindowsXP Profesional, office 2003, pemrograman databaseMicrosoft Access dan program komputer menggunakan pemrograman Visual Basic 6.0.

\section{Implementasi Program Form Menu Password}

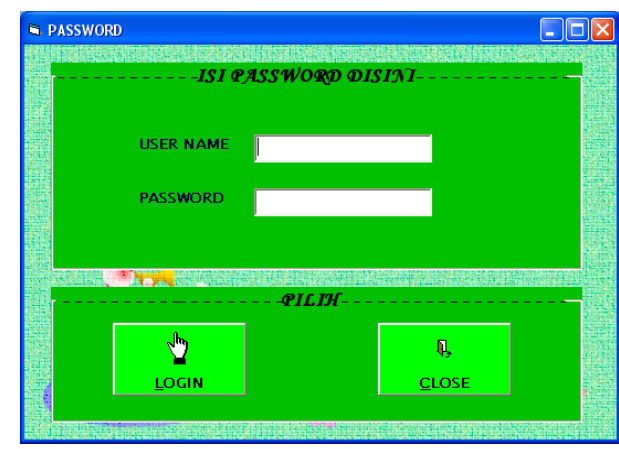

Gambar 4.13 FormPassword

Form password merupakan tampilan awal untuk masuk ke menu utama dengan mengisi user dan password, setelah itu pilih login. Bila dalam pengisian user dan password tidak sesuai dengan apa yang seharusnya, maka akan ada tampilan pesan bahwa password yang dimasukkan salah dan tampilan menu utama tidak akan tampil. Tombol close digunakan untuk keluar dari program Password.

\section{Form Menu Utama}

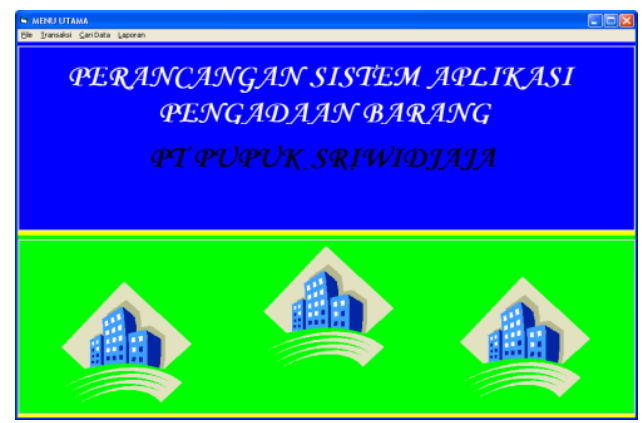

Gambar 4.14 Form Menu Utama 
Pada gambar 4.14 adalah tampilan menu utama yang terdiri dari file, transaksi, cari data dan laporan. Menu file berfungsi untuk menampilkan data-data yang akan dimasukkan yang terdiri dari data barang, data pelanggan, data distributor dan keluar. Menu Transaksi berfungsi untuk menampilkan data pemesanan, data data pengiriman.

\section{Form Data Barang}

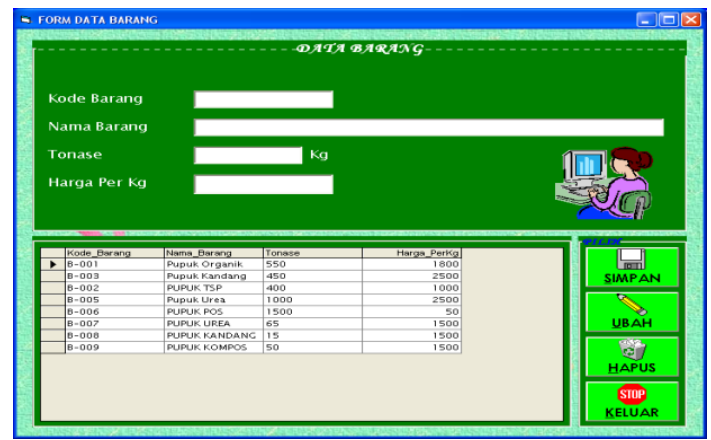

Gambar 4.15 Form Data Barang

Form data barang berfungsi untuk memasukkan data-data barang, data-data barang terdiri dari kode barang, nama barang, tonase dan harga.

Data barang memiliki tombol-tombol yang terdiri dari tombol simpan berfungsi untuk menyimpan data ke database, tombol ubah digunakan untuk memperbaiki data yang telah disimpan di dalam database, tombol hapus berfungsi untuk menghapus data yang diinginkan, tombol keluar berfungsi untuk keluar dari form data barang dan kembali ke menu utama.

\section{Form Data Pelanggan}

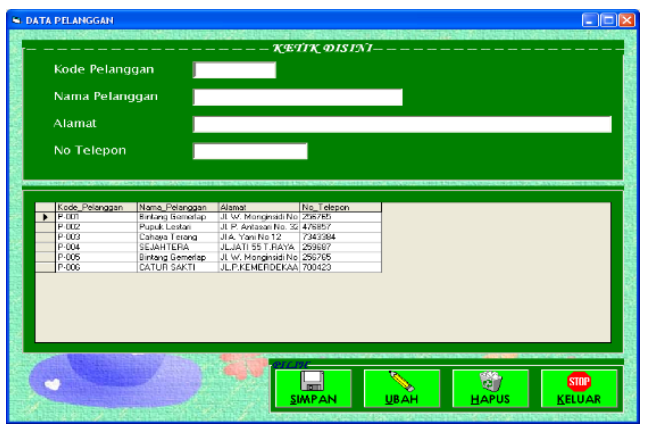

Gambar 4.16 Form Data Pelanggan

Form data pelanggan berfungsi untuk memasukkan data-data Pelanggan, data-data pelanggan terdiri dari kode pelanggan, nama pelanggan, alamat, nomor telepon.

\section{Form Data Distributor}

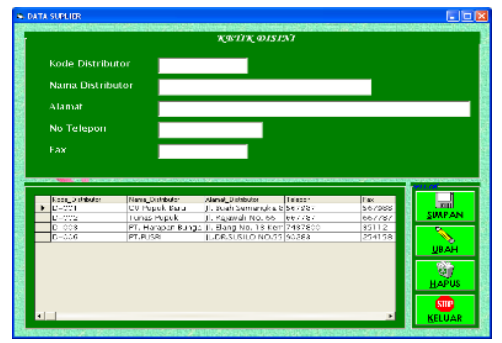

Gambar 4.17 Form Data Distributor

Form data distributor berfungsi untuk memasukkan data-data distributor yang terdiri dari kode distributor, nama distributor, alamat, no telepon, fax.

\section{Form Data Pemesanan}

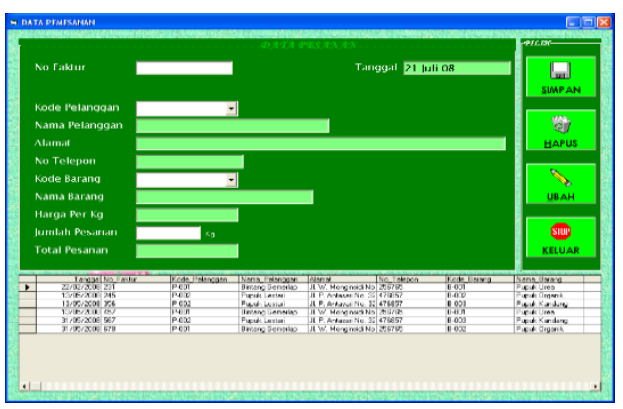

Gambar 4.18 Form Data Pemesanan

Form data pemesanan berfungsi untuk memasukkan data-data pesanan, data pesanan terdiri dari no faktur pemesanan, tanggal, kode pelanggan, nama pelanggan, alamat, nomor telepon, kode barang, nama barang, tonase dan harga.

\section{Form Data Pengiriman}

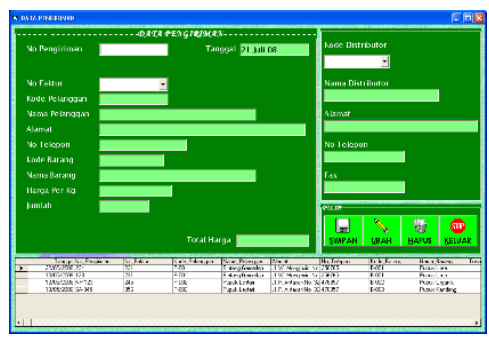

Gambar 4.19 Form Data Pengiriman Form data pengiriman berfungsi untuk memasukkan data-data pengiriman. 


\section{Form Cari Data Barang}

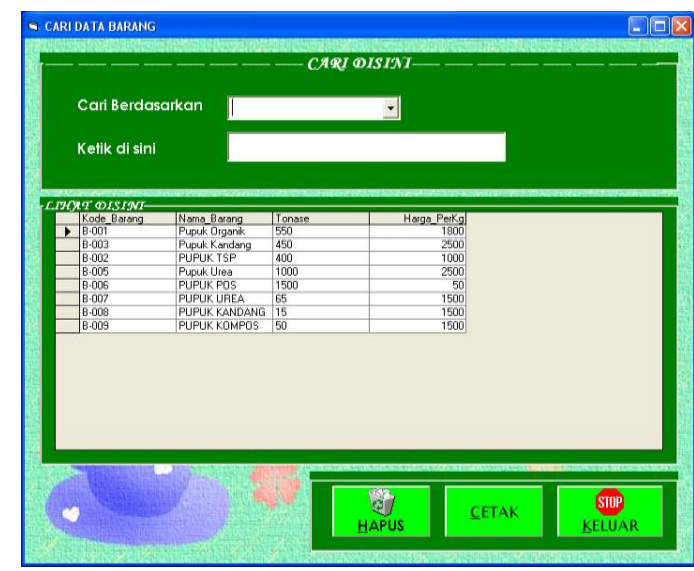

Gambar 4.20 Form Cari Data Barang

Form cari data barang merupakan form yang berfungsi untuk mencari data barang. Form cari data barang terdiri dari tombol cetak yang berfungsi untuk mencetak data yang diinginkan, dan tombol keluar berfungsi keluar dari form cari data barangdan kembali ke menu utama

\section{Form Cari Data Pelanggan}

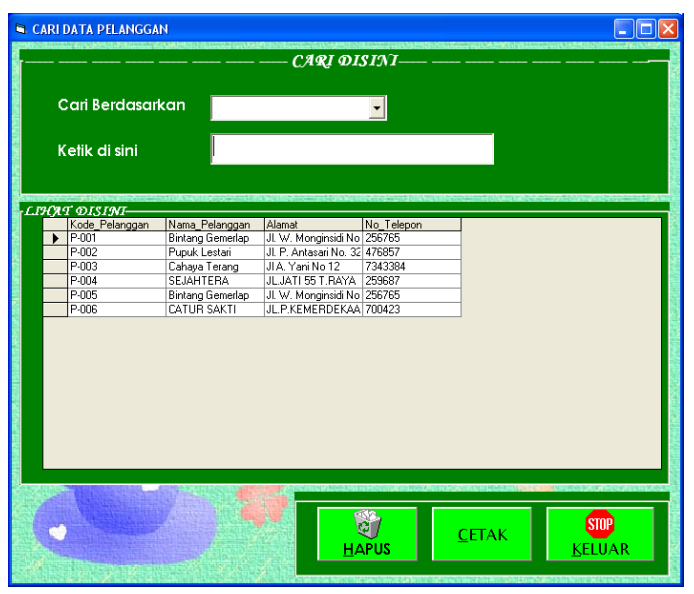

Gambar 4.21 Form Cari Data Pelanggan

Form cari data pelanggan merupakan form yang berfungsi untuk mencari data pelanggan. Form cari data pelanggan terdiri dari tombol cetak yang berfungsi untuk mencetak data yang diinginkan, dan tombol keluar berfungsi keluar dari form cari data pelanggandan kembali ke menu utama.

\section{Hasil Laporan Data DistributorHasil Laporan Pesanan Barang}

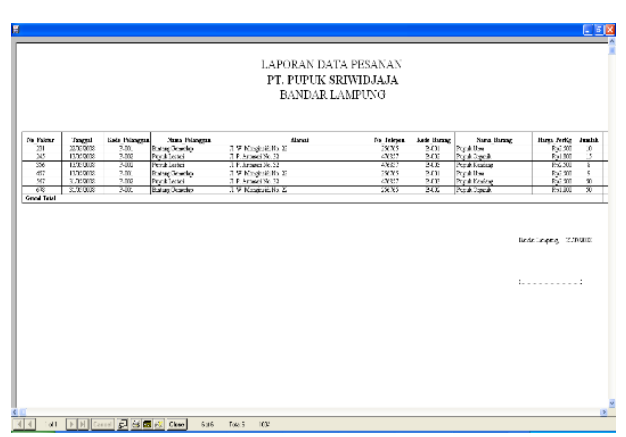

Gambar 4.27 Hasil Laporan Data Distributor

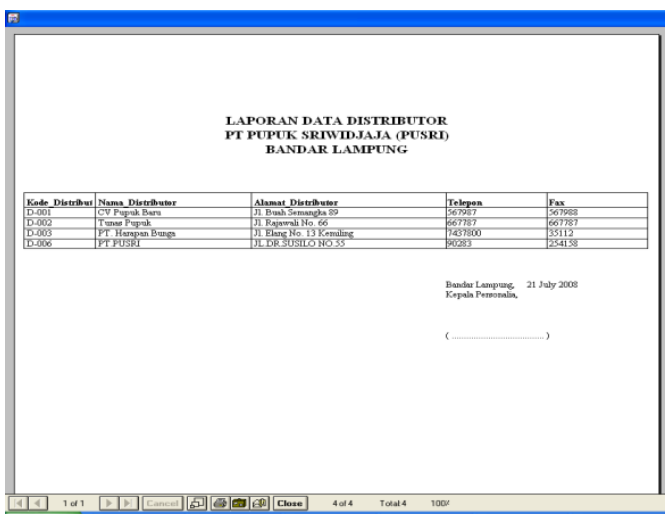

Gambar 4.28 Hasil Laporan Pesanan Barang

\section{Hasil Laporan Pengadaan Barang}

\section{SIMPULAN DAN SARAN}

Simpulan

Simpulan yang dapat diambil dari pembahasan skripsi ini yaitu:

1. PT Pupuk Sriwidjaja (Pusri) merupakan perusahaan yang sudah berkembang tetapi sistem pengolahan data dalam mengadakan barang masih menggunakan sistem manual yaitu dengan pencatatan dalam buku besar pengadaan barang.

2. Penyimpanan data-data pendukung masih belum maksimal sehingga tidak efektif dan sering terjadi kehilangan data.

3. Perancangan sistem yang penulis buat menggunakan pembuatan data flow diagram, entity relation diagram, relasi antar tabel, dan kamus data.

\section{Saran}

Sistem yang sedang berjalan pada perusahaan masih kurang efektif untuk sebuah perusahaan besar, maka penulis memberikan saran sebagai berikut:

1. Sebaiknya digunakan sistem penjualan secara terkomputerisasi untuk dapat mempermudah proses pembuatan laporan dan penyimpanan. 
2. Sistem komputerisasi yang telah penulis buat sebaiknya dapat dikembangkan kembali oleh pihak perusahaan sehingga dapat digunakan oleh perusahaan.

3. Pembuatan rancangan sistem secara terkomputerisasi sebaiknya menggunakan proses-proses seperti yang telah penulis buat.

\section{DAFTAR PUSTAKA}

HM, Jogiyanto. 1999. Analisis dan Desain Sistem Informasi Pendekatan Terstruktur Teori dan Praktek Aplikasi Bisnis. Andi. Yogyakarta.

HM, Jogiyanto. 1999. Pengenalan Komputer. Andi. Yogyakarta.

Kurniadi, Adi. 2000. Pemrograman Microsoft Visual Basic 6. ElexMedia Komputindo. Jakarta.

Marlinda, Linda. 2004. Sistem Basis Data. Andi.

Yogyakarta.

Mulyadi. 2001. Sistem Akuntansi. Salemba Empat.

Jakarta.

Sutabri, Tata. 2003. Analisis Sistem Informasi.

Andi. Yogyakarta. 